\title{
VOICE-BASED HOME SECURITY AND SMS GATEWAY USING ARDUINO UNO MICROCONTROLLER AND PASSIVE INFRA RED SENSOR
}

\author{
Yuda Irawan $^{1 *}$, Yulisman ${ }^{2}$, Naima Belarbi ${ }^{3}$, Mbunwe Muncho Josephine ${ }^{4}$ \\ STMIK Hang Tuah Pekanbaru, Indonesia ${ }^{1,2}$ \\ Faculté des Sciences Ben M'Sick, Casablanca, Morocco ${ }^{3}$ \\ University of Nigeria Nsukka, Nigeria ${ }^{4}$ \\ yudairawan89@gmail.com ${ }^{1}$, yulismanaziera27@gmail.com², naima.belarbi- \\ etu@etu.univh2c.ma ${ }^{3}$, muncho.mbunwe@unn.edu.ng ${ }^{4}$
}

Received : 0 September 2021, Revised: 26 December 2021 , Accepted : 26 December 2021

*Coresponding Author

\begin{abstract}
The development of advanced Information Technology by greatly improving human thought patterns. This home security problem can be overcome with a security system that can be delivered to homeowners via SMS notification (Short Message Service) compilation of plow sensors accepting people who enter the compilation house when it is installed and the system is in standby and the alarm will sound and the sound module has been designed to provide information about the movement in the house. To minimize this crime, the need for tools that can help improve home security. Based on the overall system test results in accordance with the desired that the security system can be used in a supported system, where when the PIR sensor supports movement the buzzer will sound, the red LED lights up, the sound module issues the expected voice message and the GSM module will send a message to the homeowner's mobile number. PIR sensor will work optimally if the object is detected by humans with a maximum distance of 6 meters. While for animals (cats), the success is only 40\%, and plants cannot be detected at all by the PIR sensor and the GSM module will send a verification message to the cellphone owner in less than 1 minute. This tool is more effectively used in a room that provides valuable items, for example in a room or other room.
\end{abstract}

Keywords : SMS Gateway, Arduino, Home Security, Infra Red

\section{Introduction}

The development of information technology that is advancing rapidly greatly affects the human mindset. Humans really want a comfortable and safe atmosphere in carrying out various activities(Gunawan, et. al., 2020; Qasim, et. al., 2020). In fact, in today's world where technological developments are increasingly sophisticated, the security of a place or room can be penetrated in various ways, for example by destroying a door, entering through a window or breaking through a roof. Limited human resources to monitor a room or a house result in criminal acts that occur, for example, theft of goods in the room(Shakthidhar, et. al., 2019). One of the desires of humans is to feel the safety of themselves and their environment, so that people think of making a tool that can see the safety conditions of the environment around them without having to be monitored from their eyes(Yar, et. al., 2021). So that every activity and person who enters the room can be directly observed and monitored. Theft based on Article 362 of the Criminal Code is an act of taking goods or something that is wholly or partly owned by another person with the intention of being forcibly owned(Pande, et. al., 2019).

Advances in electronic technology have contributed to the development of a reliable security system. One of them is a security system application for home security(Baria \& Bhatt, 2017). Many electronic devices are used for home security systems, for example, such as detecting devices for thieves, fires, and gas leaks. There are so many versions of the tools that are sold, both in terms of quality, brand, and price(Nayyar, et. al., 2017). However, the tools that are often found in the market are sold separately and are relatively more expensive. The loss if we buy a tool in a separate state, the automatic level of home security will be reduced and will also incur greater costs for purchasing the tool(Irawan \& Wahyuni, 2021). The main advantage 
of a security system based on Arduino compared to conventional security systems is that it has the ability to operate continuously and can automatically connect with other devices(Wadhwani, et. al., 2018).

Home security when the owner is left alone is of course very important, considering that very valuable assets are usually kept in the house. Fires and thefts can occur when the house is empty where the owner lives. This home security problem can be overcome with a security system that can notify the home owner via an SMS (Short Message Service) notification when the PIR sensor detects a person entering the house when the house is locked and the system is in standby and the alarm will sound and the module Sounds that have been designed can provide notification that there is movement in the house(Nwalozie, et. al., 2015). This sound module is designed to provide notification if someone enters the house and has been detected by the system, the sound module will sound as desired. To make the desired sound we need to record the sound first(Choudhury, et. al., 2015).

To minimize this crime, it is necessary to have a tool that can help improve security at home. The tool in question is a Home Security Alarm, this alarm can work by detecting movement by the PIR Sensor and if it has been detected by the system, the system will make a sound and send a message to the home owner so that the home owner can find out whether there are people in his house or not(Anitha, 2017).

Research conducted by (Samudra, 2019) by title Home Security System Using Pir Sensor And Magnetic Switch Via Sms Notification Based On Arduino Uno. Using the sim900A GSM module as a module that will send notifications in the form of SMS to homeowners. When the sensor detects human movement or detects an open door, sim900A will send an SMS alert to the number of the home owner.

Research conducted by (Permana Bayu, 2020) by title Portable Module For IoT-Based Energy Saving Smart Home. This study aims to design a smart contact box in a smart home based on Internet of Things (IoT) technology in order to monitor the amount of power consumption of electronic devices in the household, detect people in the room, and remote electronic devices in the household. The sensors used are 3 ACN26 current sensors and 1 voltage sensor for the ESP12-E MCU Node Module, Arduino nano and Raspberry Pi which are used in data processing, $2 \times 16$ displays and a web server as a display of the results of power consumption.

Research conducted by (Tjahjono, et. al., 2020) by title This study aims to design and create a security system based on RFID (Radio Frequency identification). This study uses the R \& D method, namely the research method used to produce certain products and test the effectiveness of those products.

\section{Research Methods}

A frame of mind is needed in conducting research, this frame of mind will be used as a reference for the author in completing the research, the framework in research refers to the methodology used.

Design (Prototype) is the stage after the system development cycle analysis which is the definition of functional requirements, and describes how a system is formed which can be in the form of depiction, planning and sketching or arrangement of several separate elements. be a complete and functional unit, including the configuration of the hardware and software components of a system. The essence of this method is the work of developing the model into a final system(Wahyuni, et. al., 2021; Noruwana, et. al., 2020).

In addition, to model a device, several stages are needed in the development process, these stages will determine the success of a control system. 


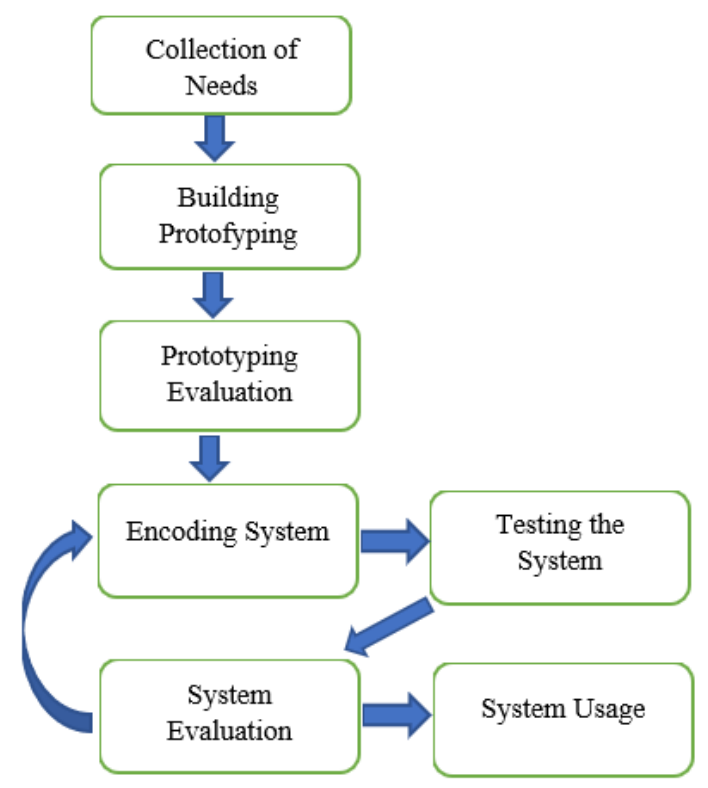

Fig. 1. Prototype Stages

a. Collection of Needs

The needs analysis stage is the stage that is carried out to obtain information on what needs are used to build a system. These needs include hardware and software. The Arduino Uno microcontroller was chosen because odet quite easy to operate and has compatibility with the various sensors available and uses the Arduino IDE software version 1.8.10 to 21odet he program(Perkasa, et. al., 2021).

b. Building Prototyping

In this stage the researcher designed a sketch drawing and a system prototype as a reference for the size of the security alarm device then proceeded with designing a home security device.

c. Prototyping Evaluation

The design that has been built will be evaluated and checked again, so that if there are still errors it can be corrected immediately(Ordila \& Irawan, 2020).

d. Encoding System

After obtaining the correct and complete design, the researcher then makes the program coding using Arduino software for the device, and also makes coding for the Android software. e. System Testing

The next stage, the tools and programs that are made are then tested whether they can function properly, testing is carried out so that the tools work as expected.

f. System Evaluation

The devices that have been tested are then evaluated again in order to get good and desirable results, if in case there are still deficiencies in the devices that are made, the devices will be revised back to the coding and testing stages, until the desired results are obtained(Rm Sari, 2021).

g. System Usage

If the manufacture of the tool is completed properly and completely, we can use the device in everyday life in the home security environment. 


\section{Results and Discussions}

Electronic design is a microcontroller system circuit design with other electronic devices such as sensors, LEDs, buzzers, jumper cables(Anamika, et. al., 2020).

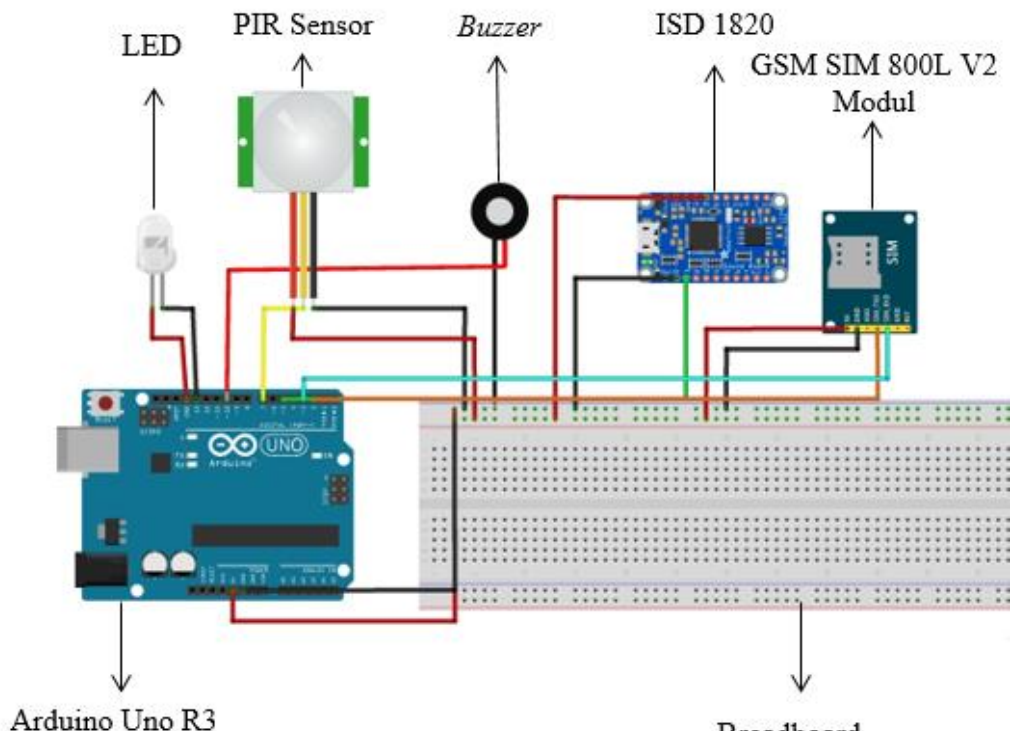

Fig. 2. Hardware Circuit Schematic

Implementation is the stage of direct application of home security system tools. This stage is also part of a development. Implementation also determines the success rate of the project that has been built(Turow, 2021).

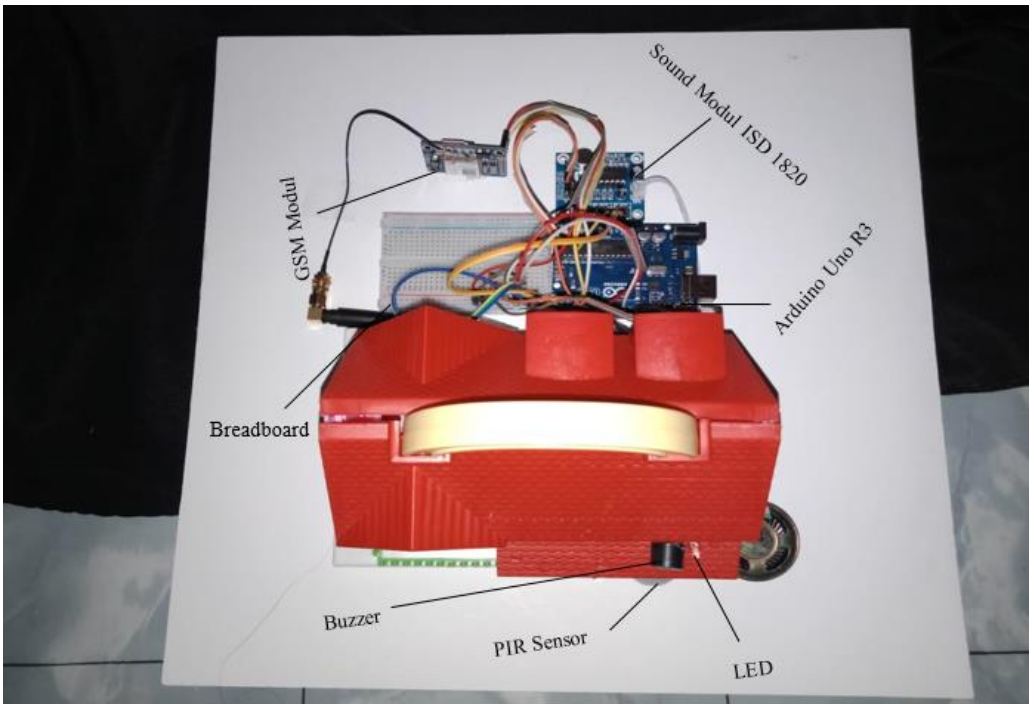

Figure 3. Back View of Home Security System Implementation

The image above is the overall picture of Voice-Based Home Alarm Security and SMS Gateway Using the Arduino Uno ATMega328 Microcontroller and PIR Sensor which consists of several components including: Arduino Uno R3, PIR Sensor, GSM Module, Sound Module, Breadboard, Buzzer and LED(Raj, et. al., 2021; Kumar, et. al., 2020). 


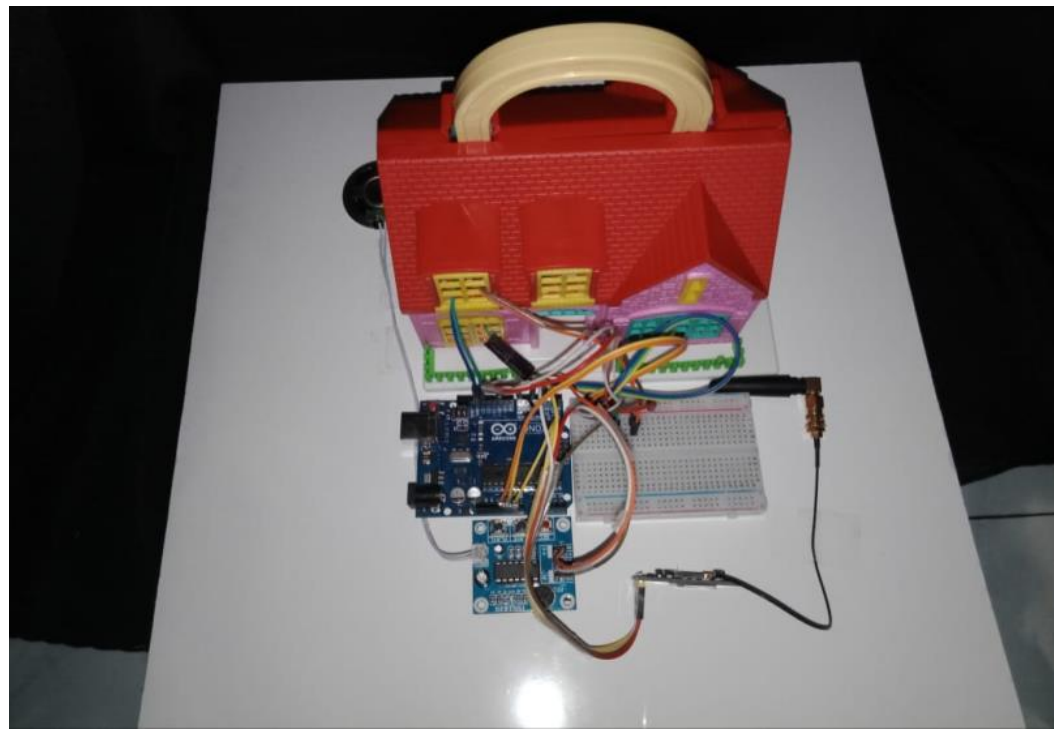

Figure 4. Overall View of Home Security System Implementation

The picture above is the implementation of the GSM module, the home owner will receive a warning message from the GSM module.

Description of the Implementation of Home Alarm Security:

1. Connect the home alarm power security cable to the electric current first

2. Next is when someone passes with a max distance of 6 meters, the pear sensor will detect the movement.

3. Next, if the movement has been detected, the microcontroller will give a signal to the led sound module and buzzer.

4. Next, when the sound module, led and buzzer work, the GSM module will send a message to the home owner's cellphone.

\section{System Testing}

The results of the implementation of the testing of the Voice-Based Home Alarm Security and SMS Gateway Implementation System Using the Arduino Uno ATMega328 Microcontroller and PIR Sensor are as follows:

Table 1 - Testing the System with a PIR Sensor

\begin{tabular}{llllll}
\hline Distance (Meter) & PIR sensor & Sound Module & LED & Buzzer & GSM Shield \\
\hline 0,5 & Detection & Sound Is On & Turns on & Beep & SMS Sent \\
1 & Detection & Sound Is On & Turns on & Beep & SMS Sent \\
2 & Detection & Sound Is On & Turns on & Beep & SMS Sent \\
3 & Detection & Sound Is On & Turns on & Beep & SMS Sent \\
4 & Detection & Sound Is On & Turns on & Beep & SMS Sent \\
5 & Detection & Sound Is On & Turns on & Beep & SMS Sent \\
6 & Detection & Sound Is On & Turns on & Beep & SMS Sent \\
7 & Not detected & No Sound & Lights off & No Sound & SMS Not Sent \\
8 & Not detected & No Sound & Lights off & No Sound & SMS Not Sent \\
9 & Not detected & No Sound & Lights off & No Sound & SMS Not Sent \\
10 & Not detected & No Sound & Lights off & No Sound & SMS Not Sent \\
\hline
\end{tabular}

The results of motion sensor testing as shown in Table 1, the PIR sensor will work optimally if the detected object is a human with a maximum distance of 6 meters. Meanwhile, for animals (cats) the success is only $40 \%$, and plants cannot be detected by the PIR sensor at all. 


\section{Conclusion}

Some conclusions that can be drawn based on the results of the analysis, design and implementation that have been carried out, and based on the formulation of the existing problems are as follows: When the house is abandoned, the home owner can monitor the security of the house through a warning message sent by the GSM module to the home owner's cellphone, so that the home owner can find out the security status of his home. This tool is more effectively used in a private room where valuables are found, for example in a room or other room. Based on the test results, the overall system is as desired, namely the security system can work in an integrated system, where when the PIR sensor detects movement, the buzzer will sound, the red LED lights up, the sound module issues a pre-recorded voice message and the GSM module will send a message to the home owner's mobile number.

\section{References}

Anamika, S. A., Khan, M. A. R., Sefat, M. M. H., \& Kibria, M. G. (2020). Internet of ThingsBased Smart Security Provisioning Using Voice-Controlled Door Locking System. In Proceedings of International Joint Conference on Computational Intelligence (pp. 439452). Springer, Singapore.

Anitha, A. (2017, November). Home security system using internet of things. In IOP conference series: materials science and engineering (Vol. 263, No. 4, p. 042026). IOP Publishing.

Baria, S. H., \& Bhatt, C. (2017). Personal and intelligent home assistant to control devices using raspberry pi. International Journal of Computing and Digital Systems, 6(04), 213-220.

Choudhury, B., Choudhury, T. S., Pramanik, A., Arif, W., \& Mehedi, J. (2015, March). Design and implementation of an SMS based home security system. In 2015 IEEE International Conference on Electrical, Computer and Communication Technologies (ICECCT) (pp. 1-7). IEEE.

Gunawan, T. S., Mokhtar, M. N., Kartiwi, M., Ismail, N., Effendi, M. R., \& Qodim, H. (2020, September). Development of Voice-Based Smart Home Security System using Google Voice Kit. In 2020 6th International Conference on Wireless and Telematics (ICWT) (pp. 1-4). IEEE.

Irawan, Y., \& Wahyuni, R. (2021, February). Electronic Equipment Control System for Households by using Android Based on IoT (Internet of Things). In Journal Of Physics: Conference Series (Vol. 1783, No. 1, p. 012094). IOP Publishing.

Kumar, R., Sarupria, G., Panwala, V., Shah, S., \& Shah, N. (2020, July). Power Efficient Smart Home with Voice Assistant. In 2020 11th International Conference on Computing, Communication and Networking Technologies (ICCCNT) (pp. 1-5). IEEE.

Nayyar, C., Valarmathi, B., \& Santhi, K. (2017, April). Home security and energy efficient home automation system using arduino. In 2017 International Conference on Communication and Signal Processing (ICCSP) (pp. 1217-1221). IEEE.

Noruwana, N. C., Owolawi, P. A., \& Mapayi, T. (2020, November). Interactive IoT-based Speech-Controlled Home Automation System. In 2020 2nd International Multidisciplinary Information Technology and Engineering Conference (IMITEC) (pp. 1-8). IEEE.

Nwalozie, G. C., Aniedu, A. N., Nwokoye, C. S., \& Abazuonu, I. E. (2015). Enhancing home security using SMS-based Intruder Detection System. International Journal of Computer Science and Mobile Computing, 4(6), 1177-1184.

Ordila, R., \& Irawan, Y. (2020). Penerapan Alat Kendali Kipas Angin Menggunakan Microcontroller Arduino Mega 2560 Dan Sensor Dht22 Berbasis Android. Riau Journal Of Computer Science, 6(2), 101-106.

Pande, K., Pradhan, A., Nayak, S. K., Patnaik, P. K., Champaty, B., Anis, A., \& Pal, K. (2019). Development of a voice-controlled home automation system for the differently-abled. In Bioelectronics and Medical Devices (pp. 31-45). Woodhead Publishing.

Perkasa, R., Wahyuni, R., Melyanti, R., \& Irawan, Y. (2021). Light Control Using Human Body Temperature Based on Arduino Uno and PIR (Passive Infrared Receiver) Sensor. Journal of Robotics and Control (JRC), 2(4), 307-310. 
Permana Bayu, G. J. (2020). Modul Portabel Untuk Rumah Cerdas Hemat Energi Berbasis IoT (Doctoral dissertation, Universitas Pendidikan Ganesha).

Qasim, H. H., Hamza, A. E., Ibrahim, H. H., Saeed, H. A., \& Hamzah, M. I. (2020). Design and implementation home security system and monitoring by using wireless sensor networks WSN/internet of things IOT. International Journal of Electrical and Computer Engineering, 10(3), 2617.

Raj, K. M., Balaji, N., Jayanthi, G., Naveen, P., Vengatesan, S., \& Aakash, A. M. (2021, March). Voice-O-Mata Using IOT. In IOP Conference Series: Materials Science and Engineering (Vol. 1084, No. 1, p. 012124). IOP Publishing.

Samudra, R. I. (2019). Sistem Keamanan Rumah Menggunakan Sensor Pir Dan Magnetic Switch Via Notifikasi Sms Berbasis Arduino Uno (Doctoral Dissertation, Politeknik Negeri Sriwijaya).

Sari, Ria Mutiara, et al. Implementation of Open and Close a Housing Gate Portal Using RFID Card. Journal of Robotics and Control (JRC), 2021, 2.5: 363-367.

Shakthidhar, S., Srikrishnan, P., Santhosh, S., \& Sandhya, M. K. (2019, March). Arduino and NodeMcu based Ingenious Household Objects Monitoring and Control Environment. In 2019 Fifth International Conference on Science Technology Engineering and Mathematics (ICONSTEM) (Vol. 1, pp. 119-124). IEEE.

Tjahjono, G., Nugraha, A. A., \& Ray, F. F. (2020). Rancang Bangun Sistem Pengaman Menggunakan Rfid. Jurnal Spektro, 3(2), 1-6.

Turow, J. (2021). Journalism and the Voice Intelligence Industry. Digital Journalism, 9(7), 1000-1006.

Wadhwani, S., Singh, U., Singh, P., \& Dwivedi, S. (2018). Smart home automation and security system using Arduino and IOT. International Research Journal of Engineering and Technology (IRJET), 5(2), 1357-1359.

Wahyuni, R., Rickyta, A., Rahmalisa, U., \& Irawan, Y. (2021). Home security alarm using Wemos D1 and HC-SR501 sensor based telegram notification. Journal of Robotics and Control (JRC), 2(3), 200-204.

Yar, H., Imran, A. S., Khan, Z. A., Sajjad, M., \& Kastrati, Z. (2021). Towards Smart Home Automation Using IoT-Enabled Edge-Computing Paradigm. Sensors, 21(14), 4932. 